\title{
Em busca do "príncipe": discursos afetivo-sexuais e representações de gênero no Culto das Princesas.
}

\section{Resumo}

Autora: Luiza V. Terassi Hortelan (IC)

O Culto das Princesas é uma campanha missionária criada em dois mil e onze, pela pastora Sarah Sheeva, que transmite conselhos cristãos sobre amor, sexo e relacionamento a mulheres solteiras, ensinando-as a tornarem-se "princesas", dignas de encontrar um "príncipe preparado por Deus". Esta pesquisa propõe uma reflexão sobre representações acerca do amor e da sexualidade produzidas em tais discursos, questionando como elas se articulam entre si na construção de feminilidades e masculinidades idealizadas (o príncipe e a princesa) e como se vinculam a processos sociais em curso na contemporaneidade, como a secularização e liberalização sexual.

Palavras Chave: Culto das Princesas, Gênero, Pentecostalismo.

\section{Introdução}

Criado em 2011, o Culto das Princesas é uma campanha evangélica de aconselhamento sentimental a mulheres solteiras, que estão em busca de seu príncipe. Idealizado pela pastora Sarah Sheeva, o Culto tem como missão principal restaurar a cultura de relacionamentos, transmitindo ensinamentos sobre amor, sexo, autoestima e comportamento. Através de prescrições como abstinência sexual e autocontrole emocional, o Culto produz e hierarquiza modelos de feminilidade: a princesa, que se valoriza, que escolhe se guardar, esperar no Senhor, e a cachorrete que se deixa levar por emoções, cai em tentação, não se ama e, portanto, não é valorizada pelos homens.

O objetivo dessa pesquisa é analisar as representações e convenções de gênero produzidas por esse discurso, compreendendo como a construção de modelos estereotipados de feminilidade e masculinidade se articula a noções particulares de amor e romantismo. Interessa-me ainda a retomada de certos valores morais, como a pureza sexual e a castidade, em um contexto social de profundas mudanças nas relações afetivas, nas moralidades sexuais e na própria religião.

\section{Resultados e Discussão}

A metodologia utilizada foi a da etnografia on e off-line, com observação participante nos cultos e eventos ligados ao Culto das Princesas, entrevistas semiestruturadas e o acompanhamento de grupos e páginas relacionados, em redes sociais online.

Percebeu-se, assim, que princesa e cachorrete são categorias classificatórias baseadas menos no comportamento sexual das mulheres e mais na sua habilidade de lidar de forma racional com suas emoções. A autoestima aparece como um valor central, que possibilitaria a conquista do príncipe, de um relacionamento santo - sem sexo ou beijos até o casamento - e, finalmente, de um casamento e família felizes, baseados em uma forma verdadeira e duradoura de amor, pois construída sem a influência do prazer sexual. Baseada em uma concepção essencialista de feminilidade e uma noção romântica de amor, o Culto busca se opor às recentes mudanças sociais na área afetiva-sexual, mas acaba por ser influenciado, em seu discurso, por essas mesmas mudanças.

\section{Conclusões}

A pesquisa de campo permite concluir que a pedagogia amorosa do Culto das Princesas ressalta valores associados à feminilidades tradicionais, atrelados à concepção romântica de amor e de família. A adequação a esse modelo aparece como única forma legítima de projeto de vida e felicidade. Sobretudo, ao construir dois modelos distintos de feminilidade, tal discurso opera a hierarquização de ambos, marginalizando o que considera inadequado: o da cachorrete, aquele que expressa e vivencia mais livremente suas emoções e não preserva sua sexualidade.

\section{Agradecimentos}

Agradeço ao PIBIC-SAE pelo financiamento dessa pesquisa. À minha orientadora lara Beleli, e ao PAGU - Núcleo de Estudos de Gênero da Unicamp.

Bibliografia:

ILLOUZ, Eva. O amor nos tempos do capitalismo. Rio de Janeiro, RJ: Zahar, 2011.

MACHADO, Maria das Dores Campos. Carismáticos e pentecostais: adesão religiosa na esfera familiar.São Paulo, Autores Associados/ANPOCS, 1996 